\title{
PENINGKATAN KETERAMPILAN KOLABORASI DAN HASIL BELAJAR DENGAN MENGGUNAKAN MODEL PEMBELAJARAN TEAMS GAMES TOURNAMENT
}

Improving Collaboration Skills and Learning Outcomes Using Teams Games Tournament Learning Models

\author{
Oleh: Chrismonika Ayu Wulandari*, Rita Rahmaniati** dan Nurul Hikmah Kartini*** \\ Email: chrismonikaayuwulandari@gmail.com*, rahmaniatirita@gmail.com**2dan \\ nurulkartini77@gmail.com***
}

\begin{abstract}
ABSTRAK
Penelitian ini bertujuan untuk: (1) Mendeskripsikan aktivitas belajar peserta didik kelas V/B SDN 4 Pahandut Palangaka Raya Tahun Pelajaran 2019/2020 dengan menggunakan model pembelajaran Teams Games Tournament, (2) Mendeskripsikan keterampilan kolaborasi peserta didik kelas V/B SDN 4 Pahandut Palangka Raya dengan menggunakan model pembelajaran Teams Games Tournament, (3) Meningkatkan hasil belajar peserta didik kelas V/B SDN 4 Pahandut Palangka Raya Tahun Pelajaran 2019/2020 dengan menggunakan model pembelajaran Teams Games Tournament.

Subjek penelitian ini adalah peserta didik kelas V/B SDN 4 Pahandut Palangka Raya Tahun Pelajaran 2019/2020 yang berjumlah 14 orang. Jenis penelitian ini adalah Penelitian Tindakan Kelas (PTK). Teknik pengumpulan data yang digunakan yaitu observasi, angket dan tes. Analisis data yang digunakan yaitu analisis kualitatif dan kuantitatif.

Hasil penelitian ini menunjukan bahwa : (1) Aktivitas belajar peserta didik dengan menggunakan model Teams Games Tournamen pada kelas V/B SDN 4 Pahandut mencapai kriteria baik. (2) Keterampilan kolaborasi peserta didik dengan menggunakan model pembelajaran Teams Games Tournamen meningkat dan mencapai kriteria sangat tinggi. (3) Ada peningkatan hasil belajar peserta didik dengan menggunakan model Teams Games Tournamen pada kelas V/B SDN 4 Pahandut.
\end{abstract}

Kata Kunci: Keterampilan Kolaborasi, Hasil Belajar Tematik, model pembelajaran Teams Games Tournamen.

\begin{abstract}
This study aims to: (1) describe the learning activities of students in class V / B SDN 4 Pahandut Palangaka Raya for the 2019/2020 academic year using the Teams Games Tournament learning model, (2) describe the collaboration skills of class V / B students of SDN 4 Pahandut Palangka Raya using the Teams Games Tournament learning model, (3) Improving the learning outcomes of class V / B students of SDN 4 Pahandut Palangka Raya for the 2019/2020 academic year using the Teams Games Tournament learning model.
\end{abstract}

Chrismonika Ayu Wulandari*, Rita Rahmaniati** dan Nurul Hikmah Kartini***

Universitas Muhammadiyah Palangkaraya 
The subjects of this study were 14 students of class V / B SDN 4 Pahandut Palangka Raya for the 2019/2020 academic year. This type of research is Classroom Action Research (PTK). The data collection techniques used were observation, questionnaires and tests. The data analysis used was qualitative and quantitative analysis.

The results of this study indicate that: (1) The learning activities of students using the Teams Games Tournament model in class V / B SDN 4 Pahandut achieve good criteria. (2) The collaboration skills of students using the Teams Games Tournament learning model increase and reach very high criteria. (3) There is an increase in student learning outcomes using the Teams Games Tournament model in class V / B SDN 4 Pahandut.

Keywords: Collaboration Skills, Thematic Learning Outcomes, Teams learning models Games Tournament.

\section{PENDAHULUAN}

Pendidikan merupakan kegiatan atau usaha secara sadar dan terencana guna mewujudkan suasana dan proses pembelajaran agar peserta didik secara aktif mengembangkan potensi yang ada di dirinya untuk memiliki kekuatan keagamaan, kecerdasan, kemampuan, serta mengembangkan keterampilan yang ada pada dirinya. Pendidikan pada saat ini menerapkan kurikulum 2013 yang menggunakan mata pembelajaran tematik. Mata pembelajaran tematik di sekolah dasar merupakan salah satu program pembelajaran yang bertujuan untuk memberikan pembelajaran yang bermakna bagi peserta didik dengan mengaitkan beberapa mata pembelajaran kedalam satu tema pembelajaran.

Memasuki abad 21, menuntut keterampilan peserta didik untuk siap menghadapi segala tantangan dan perkembangan. Keterampilan tersebut sering diistilahkan 4C yaitu: Critical Thinking (Berpikir kritis), Collaboration (Kolaborasi),

Communication

(Komunikasi), dan Creativity (Kreativitas).

Dalam era ini sangat terasa banyak hal yang berubah ditinjau dari berbagai aspek kehidupan manusia tak terkecuali pendidikan. Dimana peserta didik dituntut akan untuk memiliki kemampuan berpikir kritis, memecahkan masalah, mampu berkomunikasi, menyerap dan menyaring informasi dengan baik, serta kemampuan bekerja sama dalam menyelesaikan persoalan yang ada. Oleh karena itu, pembelajaran yang baik dapat ditunjang dari suasana pembelajaran yang kondusif, mampu bekerja sama dengan baik serta hubungan komunikasi antara guru, peserta didik dan peserta didik lainnya dapat berjalan dengan baik. Keterampilan kolaborasi sangat penting dalam proses kegiatan pembelajaran dikelas karena dapat menambah pengetahuan peserta didik dalam mencapai tujuan pembelajaran yang diharapkan. Dengan meningkatkan keterampilan kolaborasi maka peserta didik akan menghasilkan lebih banyak pengetahuan dari pada hanya menyelesaikan pekerjaan secara mandiri, peserta didik dapat bertukar pikiran guna menyelesaikan permasalahan dalam proses pembelajaran yang mereka dapatkan.

Berdasarkan pengamatan observasi awal di SD Negeri 4 Pahandut Palangka Raya selama 1 minggu mulai tanggal 23 Oktober 2019 menunjukan bahwa pada saat proses pembelajaran yang dilakukan guru masih menggunakan model pembelajaran konvensional dengan metode ceramah. 
Peserta didik hanya mendengarkan penjelasan guru dan mengerjakan soal-soal yang diberikan sehingga proses pembelajaran yang diberikan hanya berpusat pada penyampaian materi dari guru saja.

Model pembelajaran konvensional tersebut sangat bertolak belakang dengan mata pembelajaran tematik yang harapkan. Dimana peserta didiklah yang lebih aktif pada proses pembelajaran sedangkan guru hanya sebagai fasilitator pada proses pembelajaran. Pada saat proses pembelajaran guru hanya sesekali membentuk peserta didik dalam kelompok belajar, guru memberikan tugas kelompok tanpa adanya bimbingan sehingga banyak terdapat peserta didik yang hanya numpang nama pada kelompok lebih sering bermain dan berbicara diluar materi yang diajarkan. Hal ini yang menjadi kendala atau lemahnya keterampilan kolaborasi peserta didik dalam proses pembelajaran kelompok dan masih rendahnya motivasi peserta didik untuk lebih serius dalam proses pembelajaran yang diberikan.

Kurangnya motivasi peserta didik serta kurangnya penggunaan model pembelajaran yang bervariasi dalam proses pembelajaran manjadi salah satu dampak dari rendahnya hasil belajar dan lemahnya keterampilan kolaborasi peserta didik. Dari 14 orang orang peserta didik terdapat 9 orang yang mendapat nilai dibawah Kriteria Ketuntasan Minimal (KKM). Dari data tersebut peserta didik yang memperoleh nilai di bawah KKM sebanyak 9 orang (64\%) dan peserta didik yang memperoleh nilai di atas KKM sebanyak 5 orang (36\%).

Berdasarkan fenomena yang telah diuraikan maka dapat diidentifikasikan berbagai permasalahan diantaranya : penggunaan model pembelajaran yang kurang bervariasi, peserta didik kurang semangat dalam mengikuti pembelajaran, lemahnya keterampilan kolaborasi dan rendahnya nilai hasil belajar pada mata pelajaran tematik peserta didik.

Berdasarkan identifikasi dan batasan masalah maka rumusan masalah dalam penelitian ini dapat dirumuskan sebagai berikut:

1. Bagaimana aktivitas belajar peserta didik kelas V/B SD Negeri 4 Pahandut Palangka Raya dengan menggunakan model pembelajaran Teams Games Tournament (TGT)?

2. Bagaimana keterampilan kolaborasi peserta didik kelas V/B SD Negeri 4 Pahandut Palangka Raya menggunakan model pembelajaran Teams Games Tournament (TGT)?

3. Apakah ada peningkatan hasil belajar peserta didik kelas V/B SD Negeri 4 Pahandut Palangka Raya dengan menggunakan model pembelajaran Teams Games Tournament (TGT)?

Hasil belajar merupakan sesuatu yang dicapai atau diperoleh peserta didik berdasarkan proses belajar yang telah dialami. Hasil belajar ini dinyatakan dalam bentuk pengetahuan, penguasaan, kecakapan, keterampilan dan tingkah laku yang diperoleh peserta didik berkat adanya usaha pemikiran maupun tindakan yang dinyatakan melalui hasil belajar yang didapatkan atau dicapai oleh peserta didik. Menurut Nurrita (2018:175) hasil belajar merupakan keampuan yang dimiliki peserta didik setelah mengikuti proses pembelajaran dengan menilai pengetahuan, keterampilan, serta sikap pada diri peserta didik dengan adanya perubahan tinggah laku.

Sedangkan menurut Sinar (2018:20) hasil belajar merupakan kompetensi atau 
kemampuan yang diperoleh peserta didik setelah melalui kegiatan belajar atau proses belajar yang yang meliputi aspek kognitif, afektif dan psikomotorik dengan membandingkan antara tingkah laku sebelum dan sesudah melaksanakan proses pembelajaran yang kemudian di tuangkan guru kedalam bentuk angka.

Keterampilan kolaborasi merupakan keterampilan yang diperlukan dalam pendidikan era ini, dimana proses pembelajaran berorientasi pada kemampuan peserta didik dalam bekerja sama dalam menyelesaikan permasalahan yang ditemukan baik dalam pembelajaran maupun kehidupan sosial. Menurut NEA (2011:20) dalam Puspitasari (2018:3769) collaboration skill sangat penting dalam kegiatan di kelas karena dapat melatih peserta didik dalam mencapai tujuan pembelajaran dengan cara memecahkan masalah bersama dengan kelompok. Peserta didik yang mampu berkolaborasi dengan baik akan menghasilkan lebih banyak pengetahuan, membuat siswa berkolaborasi atau bekerjasama adalah kunci dari kesuksesan di kehidupan bermasyarakat saat ini.

Menurut Greenstein (2012) dalam Redhana (2019:2241) keterampilan kolaborasi merupakan keterampilan bekerja bersama secara efektif dan menunjukan rasa hormat kepada anggota tim yang beragam yang mencakup beberapa pandangan individu, menyelesaikan masalah dan menemukan ide-ide dalam menyelesaikan tujuan, dan melatih kelancaran serta kemauan dalam membuat keputusan yang diperlukan untuk mencapai tujuan bersama. Terdapat beberapa indikator keterampilan kolaborasi yaitu sebagai berikut:
Menurut Anantyarta dan Sari (2017:37) pada keterampilan kolaborasi memiliki indikator antara lain:

1. Bekerja secara produktif menggunakan waktu secara efesien dalam menyelesaikan tugas dengan anggota kelompok.

2. Sikap saling menghargai setiap pendapat anggota dalam kegiatan diskusi antar anggota.

3. Berkompromi sesama anggota secara fleksibel demi mencapai tujuan utama menyelesaikan masalah.

4. Serta tanggung jawab bersama dan setiap anggota berkontribusi dengan melakukan yang terbaik dan mengikuti apa yang ditugaskan agar tercapai tujuan yang diharapkan.

Menurut Redhana

(2019:2244)

berkolaborasi dengan orang lain memiliki indikator antara lain:

1. Mampu bekerja secara efektif dan menghargai anggota tim yang berbeda.

2. Menunjukan fleksibilitas dan keinginan untuk menjadi orang yang berguna dalam melakukan kompromi untuk mencapai tujuan umum dalam kelompok belajar.

3. Memikul tanggung jawab dalam pekerjaan kolaboratif dari setiap anggota tim dalam menyelesaikan permasalahan pembelajaran yang ditemukan.

Menurut Kadir dan Asrohah (2015:1) pembelajaran tematik merupakan program pembelajaran yang membahas mengenai satu tema maupun topik tertentu yang kemudian dielaborasi dari berbagai aspek dan ditinjau dari berbagai perspektif mata pelajaran yang diajarkan di sekolah.

Menurut Lubis dan Azizan (2020:7) pembelajaran tematik adalah kegiatan 
pembelajaran yang memadukan materi pembelajaran ke dalam suatu tema, subtema maupun pembelajaran.

Pembelajaran tematik memiliki karakteristik yang dapat dijadikan sebagai acuan untuk dikembangkan pada proses pembelajaran. Menurut Prastowo (2019:15) pembelajaran tematik memiliki karakteristik antara lain:

1. Berpusat pada peserta didik

2. Menekankan pembentukan pemahaman dan kebermaknaan

3. Memberikan pengalaman langsung

4. Lebih memperhatikan proses dari pada hasil semata

5. Sarat dengan muatan keterkaitan

6. Memisahkan mata pelajaran tidak begitu jelas

7. Menyajikan konsep dari berbagai mata pelajaran

8. Bersifat fleksibel

9. Hasil belajar sesuai dengan minat serta kebutuhan peserta didik.

10. Menggunakan prinsip belajar sambil bermain dan menyenangkan

Model pembelajaran merupakan rencana yang dilakukan untuk mengatur materi peserta didik dan memberikan petunjuk mengajar yang tergambar secara terencana dari tahap awal hingga akhir yang di sajikan secara khas oleh pendidik. Menurut Fathurrohman (2015:30) mengatakan bahwa model pembelajaran merupakan suatu rencana yang berpijak dari teori psikologi yang digunakan sebagai pedoman bagi guru dalam merencanakan dan melaksanakan kegiatan proses belajar mengajar di dalam kelas.

Menurut Isjoni (2010:83) dalam Damayanti dan Apriyanto (2017:241) menyatakan bahwa model pembelajaran kooperatif tipe TGT merupakan salah satu model pembelajaran yang menempatkan peserta didik dalam kelompok belajar beranggotakan 4-6 orang yang memiliki kemampuan, ras dan jenis kelamin yang berbeda.

Rohmah dan Wahyudin (2016:129) pembelajaran kooperatife tipe Teams Games Tournament (TGT) peserta didik melakukan permainan dan pertandingan dengan anggota-anggota tim lain untuk mendapatkan poin. Tournament atau permainan yang disusun dari pertanyaanpertanyaan yang relevan dengan pembelajaran yang dirancang untuk mengetahui sejauh mana pengetahuan yang diperoleh peserta didik dari kegiatan kelompok.

Dalam model pembelajaran teams games tournament memiliki langkahlangkah dalam pembelajaran menurut Shoimin (2014:205) menyatakan bahwa langkah-langkah model TGT yaitu sebagai berikut:

\section{Penyajian Kelas}

Pada awal pembelajaran guru menyajikan materi atau sering juga disebut dengan presentasi kelas. Guru menyampaikan tujuan pembelajaran, pokok materi, dan penjelasan mengenai lembar kerja peserta didik. Pada saat penyajian kelas, peserta didik harus benar-benar memperhatikan materi yang disampaikan guru karena hal tersebut akan membantu peserta didik bekerja lebih baik ketika kerja kelompok.

2. Belajar dalam Kelompok

Guru membagi peserta didik menjadi beberapa kelompok secara heterogen. Fungsi dari belajar dalam kelompok adalah untuk lebih mendalami materi, mendiskusikan masalah-masalah, membandingkan jawaban dan memperbaiki 
kesalahan konsep yang terdapat dalam kelompok belajar peserta didik.

\section{Permainan}

Games atau permaianan terdiri dari pertanyaan-pertanyaan yang relevan dengan materi yang telah disampaikan guru. Permainan ini dirancang untuk menguji pengetahuan yang didapat peserta didik dari penyajian kelas dan belajar kelompok.

4. Pertandingan atau Lomba

Tournament atau lomba adalah struktur belajar dimana game atau permainan terjadi. Biasanya tournament dilakukan pada saat guru telah melakukan presentasi kelas dan kelompok telah mengerjakan lembar kerja peserta didik. Pada lomba guru membagi peserta didik kedalam meja tournament atau lomba.

5. Penghargaan Kelompok

Setelah tournament berakhir kemudian pendidik mengumumkan anggota kelompok yang memiliki skor tertinggi. Masing-masing kelompok yang menang akan mendapatkan hadiah apabila rata-rata skor memenuhi kriteria yang ditentukan.

Dalam setiap model pembelajaran maka akan ditemukan beberapa kekurangan dan kelebihan adapun kelebihan model pembelajaran TGT menurut Oktavia (2020:58) antara lain:

1. Lebih meningkatkan pencurahan waktu untuk tugas.

2. Dengan model pembelajaran TGT maka peserta didik akan belajar saling mengahargai pendapat.

3. Dengan model pembelajaran ini, membuat peserta didik lebih aktif dan bersemangat dalam mengikuti pelajaran.

4. Melatih peserta didik untuk bersosialisasi dengan orang lain.

5. Motivasi belajar meningkat.

6. Hasil belajar menjadi lebih baik.
Adapun beberapa kekurangan dalam model pembelajaran kooperatif tipe Teams Games Tournament (TGT) antara lain:

1. Membutuhkan waktu yang cukup lama.

2. Guru harus bertindak sebagai pemegang kendali, teliti dalam menentukan pembagian kelompok .

Adapun rumusan hipotesis dalam penelitian ini adalah sebagai berikut:

1. Aktivitas belajar peserta didik kelas V/B SD Negeri 4 Pahandut Palangka Raya dengan menggunakan model pembelajaran Teams Games Tournament (TGT) mencapai kriteria baik.

2. Aktivitas keterampilan kolaborasi peserta didik kelas V/B SD Negeri 4 Pahandut dengan menggunakan model pembelajaran Teams Games Tournamen (TGT) meningkat dan mencapai kategori tinggi

Ada peningkatan hasil belajar peserta didik kelas V/B SD Negeri 4 Pahandut dengan menggunakan model pembelajaran Teams Games Tournamen (TGT).

\section{METODE PENELITIAN}

Penelitian ini dilaksanakan pada bulan Oktober 2019 sampai dengan Maret 2020. Penelitian ini dilaksanakan di kelas V/B SD Negeri 4 Pahandut Palangkaraya, Jl. Kapten Hasanudin, Pahandut, Kec. Pahandut, Kota Palangka Raya, Kalimantan Tengah.

Dalam penelitian ini menggunakan Penelitian Tindakan Kelas (PTK) yang merupakan penelitian yang dilakukan untuk memperbaiki proses pembelajaran dikelas. Menurut Diplan dan Setiawan (2018:15) menyatakan bahawa penenlitian Tindakan

Kelas (PTK) merupakan Penelitian Tindakan yang dilakukan oleh guru 
(sebagai peneliti) dengan maksud melihat kemampuan diri dan memperbaiki kualitas proses pembelajaran sehingga aktifitas belajar peserta didik semakin meningkat, aktif dan menyenangkan.

Subjek peneliti dalam penelitian ini adalah peserta didik kelas V/B SD Negeri 4 Pahandut Palangka Raya Tahun Pelajaran 2019/2020 yang berjumlah 14 orang.

Tabel 4

Populasi Peserta Didik Kelas V/B SD

Negeri 4 Pahandut

\begin{tabular}{|c|c|c|c|}
\hline \multirow{2}{*}{ No } & \multirow{2}{*}{ Kelas } & \multicolumn{2}{|c|}{ Jenis Kelamin } \\
\cline { 3 - 5 } & Laki-laki & Perempuan \\
\hline $\mathbf{1}$ & V/B & $\mathbf{6}$ & $\mathbf{8}$ \\
\hline \multicolumn{2}{|c|}{ Jumlah } & \multicolumn{2}{|c|}{$\mathbf{1 4}$} \\
\multicolumn{2}{|c|}{ Sumber data } & $:$ Absensi kelas V/B SD
\end{tabular}

Negeri 4 Pahandut

\section{HASIL PENELITIAN DAN PEMBAHASAN}

Teknik pengumpulan data dalam penelitian ini dilakukan melalui observasi, angket dan tes.

Data kualitatif diperoleh dari lembar observasi peserta didik yang dimaksud untuk mengetahui aktivitas peneliti dan aktivitas peserta didik selama proses belajar mengajar. Sedangkan Data kuantiatif diperoleh dari hasil tes yang diberikan kepada peserta didik pada setiap akhir siklus. Hasil tes digunakan untuk mengukur keberhasilan proses pembelajaran.

Tabel 22

\section{Rekapitulasi Hasil Pengamatan Aktivitas Guru dan Peserta Didik}

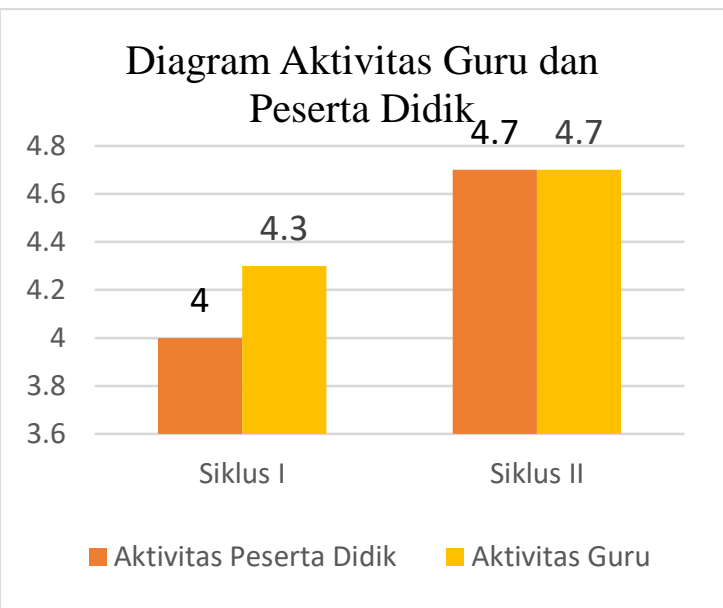

\section{Gambar 6}

Diagram Aktivitas Guru dan Peserta Didik

Berdasarkan gambar diagram di atas maka dapat disimpulkan bahwa aktivitas belajar dengan menggunakan model pembelajaran Teams Games Tournament pada setiap siklus mengalami peningkatan. Pada siklus I rata-rata aktivitas belajar peserta didik 4,0 dan pada siklus II yaitu 4,7 sedangkan pada aktivitas guru pada proses pembelajaran siklus I memproleh nilai rata-rata 4,3 dan pada siklus II yaitu 4,7. Hal ini menunjukkan bahwa dengan menggunakan model pembelajaran Teams Games Tournament aktivitas belajar peserta didik menjadi baik.

Tabel 23

Rekapitulasi Indikator Keterampilan Kolaborasi

\begin{tabular}{|c|c|c|}
\hline Data & Indikator & $\%$ \\
\hline & $\begin{array}{l}\text { a. } \text { Bekerja secara } \\
\text { produktif }\end{array}$ & $53,56 \%$ \\
\hline
\end{tabular}

\begin{tabular}{l|c|c|c|c|}
\cline { 2 - 6 } & Siklus & $\begin{array}{c}\text { Aktivitas } \\
\text { Guru }\end{array}$ & $\begin{array}{c}\text { Aktivitas } \\
\text { Peserta } \\
\text { Didik }\end{array}$ & Ket \\
\cline { 2 - 6 } & 1 & 4,3 & 4,0 & Baik \\
\hline $\begin{array}{l}\text { Chrismonika Ayu Wulandari*, Rita Rahmaniati** dan Nurul Hikmakt Kantin } \\
\text { Universitas Muhammadiyah Palangkaraya }\end{array}$
\end{tabular}




\begin{tabular}{|c|c|c|}
\hline \multirow[t]{3}{*}{$\begin{array}{c}\text { Observas } \\
\text { i Awal }\end{array}$} & $\begin{array}{l}\text { b. Saling } \\
\text { menghargai } \\
\text { anggota tim } \\
\text { yang berbeda }\end{array}$ & $62,09 \%$ \\
\hline & $\begin{array}{l}\text { c. Berkompromi } \\
\text { dan } \\
\text { berkontribusi }\end{array}$ & $58,86 \%$ \\
\hline & $\begin{array}{l}\text { d. Bertanggung } \\
\text { jawab }\end{array}$ & $58,56 \%$ \\
\hline \multirow{4}{*}{$\begin{array}{c}\text { Tes } \\
\text { Akhir } \\
\text { Siklus I }\end{array}$} & $\begin{array}{l}\text { a. Bekerja secara } \\
\text { produktif }\end{array}$ & $64,27 \%$ \\
\hline & $\begin{array}{l}\text { b. Saling } \\
\text { menghargai } \\
\text { anggota tim } \\
\text { yang berbeda }\end{array}$ & $85,7 \%$ \\
\hline & $\begin{array}{l}\text { c. Berkompromi } \\
\text { dan } \\
\text { berkontribusi }\end{array}$ & $74,27 \%$ \\
\hline & $\begin{array}{l}\text { d. Bertanggung } \\
\text { jawab }\end{array}$ & $71,42 \%$ \\
\hline \multirow{4}{*}{$\begin{array}{c}\text { Tes } \\
\text { Akhir } \\
\text { Siklus II }\end{array}$} & $\begin{array}{l}\text { a. Bekerja secara } \\
\text { produktif }\end{array}$ & $84,28 \%$ \\
\hline & $\begin{array}{l}\text { b. Saling } \\
\text { menghargai } \\
\text { anggota tim } \\
\text { yang berbeda }\end{array}$ & $89,28 \%$ \\
\hline & $\begin{array}{l}\text { c. Berkompromi } \\
\text { dan } \\
\text { berkontribusi }\end{array}$ & $86,66 \%$ \\
\hline & $\begin{array}{l}\text { d. Bertanggung } \\
\text { jawab }\end{array}$ & $85,71 \%$ \\
\hline
\end{tabular}

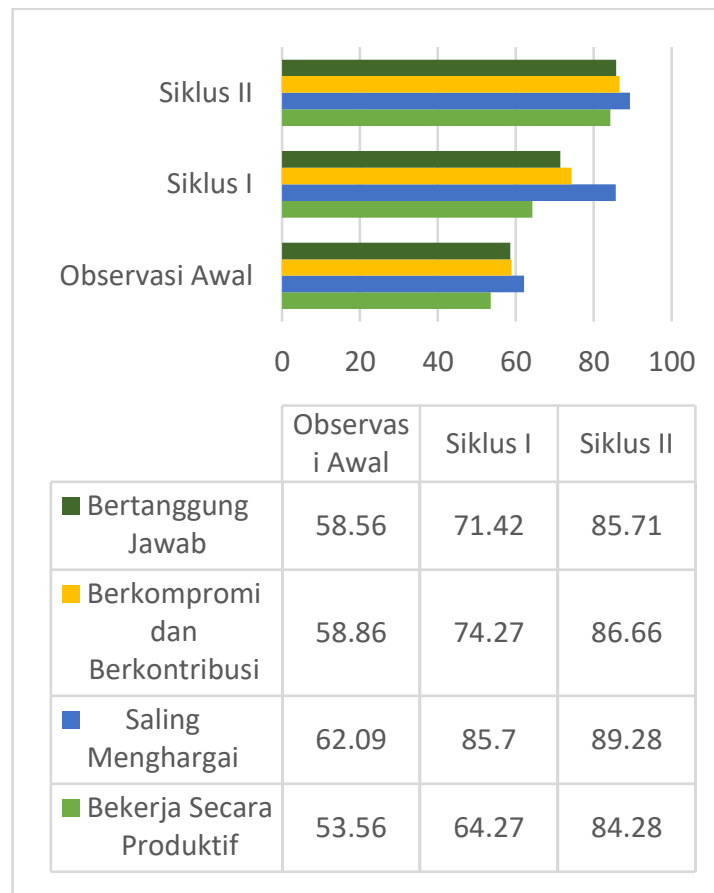

\section{Gambar 7 \\ Diagram Indikator Keterampilan Kolaborasi}

Berdasarkan tabel dan diagram diatas data awal tindakan (pre test), siklus I dan siklus II terlihat adanya peningkatan pada tiap indikator keterampilan kolaborasi disetiap siklus dengan menggunakan model pembelajaran Teams Games Tournament. Sedangkan angket rata-rata keseluruhan keterampilan kolaborasi peserta didik dapat dilihat melalui tabel dan diagram sebagai berikut:

Tabel 24

Persentase Keterampilan Kolaborasi Peserta Didik

\begin{tabular}{|c|c|c|}
\hline $\begin{array}{c}\text { N } \\
\mathbf{0}\end{array}$ & Data & $\begin{array}{c}\text { Persentase Angket } \\
\text { Keterampilan } \\
\text { Kolaborasi }\end{array}$ \\
\hline 1 & $\begin{array}{c}\text { Observasi } \\
\text { Awal }\end{array}$ & $58,42 \%$ \\
\hline 2 & $\begin{array}{c}\text { Tes Akhir } \\
\text { Siklus I }\end{array}$ & $73,71 \%$ \\
\hline 3 & $\begin{array}{c}\text { Tes Akhir } \\
\text { Siklus II }\end{array}$ \\
\hline
\end{tabular}


Berdasarkan perhitungan persentase angket keterampilan kolaborasi peserta didik di SD Negeri 4 Pahandut Palangka Raya pada observasi awal sebesar 58,42\% berada di kategori sedang. Setelah dilaksanakannya siklus I dengan menggunakan model pembelajaran Teams Games Tournamnet (TGT) memproleh persentase sebesar $73,71 \%$ keterampilan kolaborasi peserta didik mengalami peningkatan sebesar $15,29 \%$ dan berada dikategori tinggi. Sedangkan keterampilan kolaborasi pada siklus II sebesar 86,42\% dan mengalami peningkatan sebesar $12,76 \%$ dan berada pada ketegori sangat tinggi. Hal ini menunjukan keterampilan kolaborasi peserta didik telah melebihi kriteria persentase angket yang diharapkan pada keterampilan kolaborasi sebesar $\geq 75 \%$ dan berada pada kategori tinggi.

Berdasarkan data tersebut menunjukan bahwa dengan menggunakan model pembelajaran Teams Games Tournament (TGT) dapat meningkatkan keterampilan kolaborasi peserta didik kelas V/B SD Negeri 4 Pahandut Palangka Raya. Dengan menggunakan model pembelajaran Teams Games Tournament yang diterapkan guru membuat peserta didik ikut berperan aktif pada proses pembelajaran, peserta didik belajar saling menghargai pendapat dan mampu menumbuhkan rasa kebersamaan dalam anggota kelompok, kerja sama antar peserta didik membuat interaksi belajar dalam kelas tidak membosankan serta membuat peserta didik lebih bersemangat dalam mengikuti pembelajaran.

Tabel 25

Rekapitulasi Hasil Belajar Peserta Didik

\begin{tabular}{|c|c|c|c|}
\hline No & Data & $\begin{array}{c}\text { Nilai } \\
\text { Rata- } \\
\text { rata }\end{array}$ & $\begin{array}{c}\text { Persentase } \\
\text { Ketuntasan } \\
\text { Klasikal }\end{array}$ \\
\hline
\end{tabular}

\begin{tabular}{|c|c|c|c|}
\hline 1 & $\begin{array}{c}\text { Observasi } \\
\text { Awal }\end{array}$ & 61,78 & $35,71 \%$ \\
\hline 2 & $\begin{array}{c}\text { Tes Akhir } \\
\text { Siklus I }\end{array}$ & 66,07 & $64,28 \%$ \\
\hline 3 & $\begin{array}{c}\text { Tes Akhir } \\
\text { Siklus II }\end{array}$ & 93,57 & $100 \%$ \\
\hline
\end{tabular}

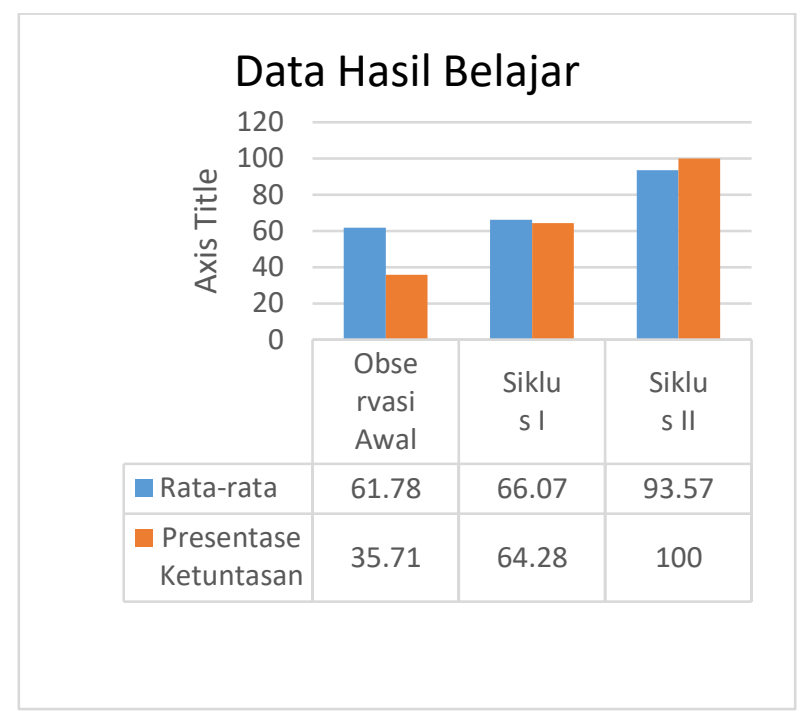

Gambar 8

\section{Diagram Ketuntasan Hasil Belajar}

Berdasarkan tabel dan diagram diatas data awal tindakan (pre test), siklus I dan siklus II terlihat adanya peningkatan hasil belajar pada mata pelajaran tematik tema 7 Subtema 1 Peristiwa Dalam Kehidupan dengan menggunakan model pembelajaran TGT.

Pada tes awal persentase ketuntasan klasikal peserta didik hanya mencapai $35,71 \%$ dengan nilai rata-rata 61,78 dengan kategori tidak tercapai, siklus I persentase ketuntasan klasikal mencapai 64,28\% dengan nilai rata-rata 66,07 kategori tidak tercapai, siklus II ketuntasan klasikal meningkat hingga mencapai $100 \%$ kategori tercapai dengan nilai rata-rata 93,57\%.

Berdasarkan data tersebut dengan menggunakan model pembelajaran TGT terjadi peningkatan hasil belajar pada tiap siklusnya. Model pembelajaran TGT 
membuat peserta didik aktif dalam menyelesaikan permasalahan yang ditemukan dan mampu mendiskusikan jawaban saat berada di dalam kelompok. Dengan penerapan model TGT dapat membuat peserta didik lebih bersemangat dalam proses pembelajaran sehingga peserta didik lebih menguasai materi pembelajaran dan hasil belajar peserta didik meningkat.

Hal ini senada dengan penelitian Yudianto, dkk (2014) bahwa pembelajaran kooperatif tipe Teams Games Tournament membuat peserta didik bertanggung jawab dan bekerjasama menguasai materi pembelajaran guna mendapatkan hasil yang maksimal. Dengan penerapan model pembelajaran TGT dapat meningkatkan hasil belajar peserta didik diringi dengan peningkatan aktivitas belajar peserta didik.

\section{KESIMPULAN}

Berdasarkan hasil penelitian maka dapat disimpulkan bahwa dengan menggunakan model pembelajaran TGT mampu membuat peserta didik bekerja sama, ikut berpartisipasi aktif pada proses pembelajaran, menghargai pendapat, bekerja produktif serta mampu membuat peserta didik bertanggung jawab dalam menyelesaikan permasalahan pembelajaran guna mencapai keberhasilan pembelajaran yang diharapkan.

Keberhasilan proses pembelajaran tersebut dapat dibuktikan dengan terjadinya peningkatan aktivitas dan hasil belajar peserta didik pada keterampilan kolaborasi dan hasil belajar peserta didik pada mata pelajaran tematik dengan menggunakan model pembelajaran TGT telah mengalami peningkatan dan melebihi kriteria keberhasilan yang telah ditetapkan. Hal ini membuktikan bahwa dengan menggunakan model pembelajaran Teams Games Tournament (TGT) mampu meningkatkan aktivitas, keterampilan kolaborasi dan hasil belajar peserta didik di kelas V/B SDN 4 Pahandut Palangka Raya.

\section{DAFTAR PUSTAKA}

Anantyarta, P., \& Sari, R. L. 2017. Keterampilan Kolaboratif dan Metakognitif Melalui Multimedia Berbasis Means Ends Analysis. Jurnal Biologi dan Pembelajaran Biologi, 2(2):33-43.

Damayanti, S., \& Apriyanto, M. T. 2017. Pengaruh Model Pembelajaran Kooperatif Tipe TGT (Teams Games Tournament) Terhadap Hasil Belajar Matematika. JKPM (Jurnal Kajian Pendidikan Matematika), 2(2), 235244.

Diplan, \& Setiawan, Andi. 2018. Penelitian

Tindakan Kelas. Yogyakarta: DEEPUBLISH.

Fathurrohman, M. 2015. Model-model Pembelajaran Inovatif. Jogjakarta: AR-RUZZ MEDIA.

Kadir, A., \& Asrohah, H. 2015. Pembelajaran Tematik. Jakarta: PT Rajagrafaindo Persada.

Lubis, M. A., \& Azizan, N. 2020. Pembelajaran Tematik SD/MI. Jakarta: KENCANA.

Nurrita, T. 2018. Pengembangan Media Pembelajaran Untuk Mengingkatkan Hasil Belajar Siswa. Misykat , 03 (01), 171-178.

Octavia, S. A. 2020. Model-Model Pembelajaran. Yogyakarta: Deepublish.

Prastowo, A. 2019. Analisis Pembelajaran Tematik Terpadu. Jakarta: Kencana.

Puspitasari, N. 2018. Peningkatan Collaboration Skill Siswa Sebagai 
Kecakapan Abad 21 Melalui Pembelajaran Model Cooperative Learning Tipe Team Accelerated Instruction (TAI) Mata Pelajaran IPA di SD Negeri KOTAGEDE 1. Jurnal Pendidikan Guru Sekolah Dasar Edisi 38 Tahun ke-7, 3767-3780.

Rahmaniati, R., Aslamiyah, J., \& Lastaria, L. 2019. Penerapan Model Pembelajaran TAI Untuk meningkatkan Hasil Belajar Matematika peserta Didik kelas IV MIN-2 Kota Palangkaraya. Jurnal Hadratul Madaniyah, 6(2):29-34.

Redhana, I. W. 2019. Mengembangkan Keterampilan Abad Ke-21 Dalam Pembelajaran Kimia. Jurnal Inovasi Pendidikan Kimia, 13(1):2239-2253.

Rohmah, E. A., \& Wahyudin. 2016. Pengaruh Model Pembelajaran Kooperatif Tipe Teams Games Tournament (TGT) Berbantuan Media Game Online Terhadap Pemahaman Konsep dan Penalaran Matematis Siswa. Edu Humaniora: Jurnal Pendidikan Dasar, 8(2):126143.

Setiawan, Redno \& Iin Nurbudiyani. 2018. Peningkatan Hasil Belajar Ekonomi Dengan Menggunakan Model Pembelajaran Kooperatif Tipe Jigsaw Kelas XI IIS SMA Negeri 2 Palangka Raya. Jurnal Neraca 3(1):45-51.

Shoimin, A. 2014. 68 Model Pembelajaran Inovatif dalam Kurikulum 2013. Yogyakarta: AR-RUZZ MEDIA.

Sofyana, Anisa \& Sonedi. 2020. Pemanfaatan Perpustakaan Sekolah Sebagai Penunjang Kegiatan Belajar dalam Meningkatkan Hasil Belajar Ekonomi Peserta Didik Kelas X IIS pada SMAN-3 Palangka Raya. Jurnal Neraca 3(1):1-6.
Sinar. 2018. Metode Active Learning. Yogyakarta: DEEPUBLISH.

Yantol, R., Diplan, D., \& Kartini, N. H. 2018. Upaya Meningkatkan Hasil Belajar Ipa dengan Model Pembelajaran Scramble-Media Visual Peserta Didik Kelas IV SDN 4 Panarung Tahun Pelajaran 2017/2018. Jurnal Hadratul Madaniyah, 5(1):27-31.

Yudianto, W. D., Sumardi, K., \& Berman, E. T. 2014. Model Pembelajaran Teams Games Tournament Untuk Meningkatkan Hasil Belajar Siswa SMK. Journal of Mechanical Engineering Education, 1(2). 